\title{
The effect of calving season on reproductive performance of Jersey cows
}

\author{
doi: $10.15567 /$ mljekarstvo.2017.0407 \\ Ercan Soydan*, Mehmet Kuran \\ University of Ondokuz Mayıs, Department of Agricultural Biotechnology, Samsun, Turkey \\ Received - Prispjelo: 13.03.2017. \\ Accepted - Prihvaćeno: 27.09.2017
}

\begin{abstract}
Dairy records, containing 1269 lactation record of 462 Jersey dairy cows collected over 16 years, from an agricultural state farm were used. Data for reproductive performance of cows were also collected. Means of the herd for lactation milk yield, calving interval, days open, interval from calving to the first insemination, lactation length, gestation length and dry period were $3195.7 \pm 20.2 \mathrm{~kg}$, $366.6 \pm 1.7 \mathrm{~d}, 92.9 \pm 1.6 \mathrm{~d}, 78.0 \pm 1.3 \mathrm{~d}, 301.7 \pm 1.1 \mathrm{~d}, 275.2 \pm 0.2 \mathrm{~d}$ and $69.3 \pm 0.8 \mathrm{~d}$, respectively. The effect of calving season (winter, spring, summer and autumn) on reproductive performance for high, low and moderate milk-yield cows was investigated. Calving season affected the days from calving to first insemination in high and moderate yielding cows $(\mathrm{P}<0.001)$ while didn't affect low yielding cows. In summer, days open in high yielding cows were 35 days longer compared to winter season $(\mathrm{P}<0.001)$ as observed for moderate yielding cows $(\mathrm{P}<0.01)$. In high yielding cows, calving interval was 18 days longer in spring compared to winter calving season. Calving season also affected the first service conception rate in high yielding cows $(\mathrm{P}<0.05)$. Services per conception in autumn were lower than the other seasons $(\mathrm{P}<0.001)$. In conclusion, high yielding dairy cows need more attention in summer season with respect to body condition score, dietary energy: protein ratio, uterus health and elimination of heat stress, to get more profit in dairy farm.
\end{abstract}

Key words: Jersey cow, reproductive performance, calving season

\section{Introduction}

Genetic selection has resulted in a dramatic increase in milk yield in dairy cows over the years. However, rapid worldwide progress in genetics of high producing dairy herds, reproductive efficiency has been suffered a dramatic decrease since the mid 1980s (Garcia-Ispierto et al., 2007). The decline in fertility in modern dairy cows is major concern, because the profitability of dairy herds greatly depends on fertility which has been often linked to a rising milk yield in high producing dairy cattle (Lucy, 2001). A decline in dairy cow fertility has been observed in European countries (Jorristma et al., 2000; Roche et al., 2000; Royal et al., 2000; Pryce and Veerkamp, 2001; Lopez-Gatius, 2003;
Nemeckova, et al., 2015), Australia (Macmillan et al., 1996), South Africa (Muller et al., 2000) and the United States (Lucy, 2001). Surveys over the last 5-10 years showed that the decline in conception rate was around $0.5 \%$ and $1 \%$ per year (Butler and Smith, 1989; Royal et al., 2000; Chevallier and Humblot, 1998; Boichard et al., 2002a; Freret and Chevallier, 2002). But, the decrease in reproductive efficiency in dairy cows worldwide is not solely due to increase in milk yield. A high milk yield will only provoke a higher risk of infertility under suboptimal conditions, such as inadequate nutrition or environment (Fahey et al., 2002; Calus et al., 2005). There are equally important other factors contributing to the problem. 
Lopez-Gatius et al (2005) observed no relationship between milk production at artificial insemination (AI) and conception rates in two studies performed in high producing dairy herds. Also, Boichard et al. (1998) and Grimard et al. (2006) reported that only 30-50\% of the decline in first service conception rate could be explained by the increase in milk production due to genetic improvement. These studies showed that, reduced reproductive efficiency in high yielding dairy cows may be due to an imbalance of nutrients or diets not matched to performance (Pryce et al., 2004), negative energy balance of the cow, metabolic heat increment and global warming.

The impacts of heat stress on reproductive efficiency have been well documented (Hansen and Arechiga, 1999; Wolfenson et al., 2000; Kadzere et al., 2002; Jordan, 2003; De Rensis and Scaramuzzi, 2003; Sattar et al., 2004). Seasonal changes on the reproductive performance of dairy cows have been reported and the effect of season has been attributed to the heat stress rather than changes in vegetation (De Rensis and Scaramuzzi, 2003). However, the calving season (e.g., autumn or spring) and the distribution of calving dates (e.g., calving earlier or later within the spring season) within the herd have major effects on the herd's pattern of feed demand and its supply of milk through the year and also reproductive performance. When the time of high protein in pasture coincides with the time of the breeding season (O'Callaghan and Boland, 1999; Garcia-Peniche, 2004) or when cows cannot meet their energy requirements solely from ingested feed and they mobilize body energy to meet the deficit, which this state is commonly known as negative energy balance, excess protein intake and negative energy balance may affect reproduction negatively (Doepel et al., 2002; Coffey et al., 2004).

These findings highlight the need to gain further knowledge on high producing management routines in different environments to improve both the production and fertility of dairy herds. Therefore in the present study, we tested whether calving season is a cause of decreased reproductive efficiency (days from calving to first insemination, days open, calving interval and pregnancy rate at first insemination) in high yielding Jersey cows.

\section{Material and methods}

Dairy records from the Karakoy Agricultural Farm in Black Sea Region of Turkey $\left(41^{\circ} 30^{\prime} \mathrm{N}\right.$ and $\left.36^{\circ} 06^{\prime} \mathrm{E}\right)$ were used in this study. This data contained 1269 lactation record of 462 Jersey dairy cows collected over 16 years. Data for reproductive performance of cows were also collected. Data for cows between $1^{\text {st }}$ and $5^{\text {th }}$ lactation were used. The mean lactation milk yield of the herd was $3195.7 \pm 20.2 \mathrm{~kg}$. Means of the herd for calving interval, open days, interval from calving to the first insemination, lactation length, gestation length and dry period were $366.6 \pm 1.7 \mathrm{~d}, 92.9 \pm 1.6 \mathrm{~d}, 78.0 \pm 1.3 \mathrm{~d}, 301.7 \pm 1.1 \mathrm{~d}$, $275.2 \pm 0.2 \mathrm{~d}$ and $69.3 \pm 0.8 \mathrm{~d}$, respectively.

Climatic data were obtained from State $\mathrm{Me}-$ teorological Service of Turkey (SMST) (Figure 1; Samsun, Turkey). Average maximum, minimum, and daily temperatures on a monthly basis and average relative humidity were calculated. The average monthly temperature and humidity during the experimental period was similar to the mean monthly values for 30 years (SMST, 2014).

Lactation milk yield of cows were classified into 3 yielding levels; cows with the milk yield of 1 standard deviation above the herd mean was considered as high yielding cows, those of 1 standard deviation below the herd mean was considered as low yielding cows, and cows with the milk yield between these limits were considered as average yielding cows (Table 1). Then, reproductive performance data for each milk yield level were classified into four different calving seasons, namely as winter (December, January and February), spring (March, April, May), summer (June, July, August) and autumn (September, October, November). Means of milk yield for these calving seasons are summarized in Table 1.

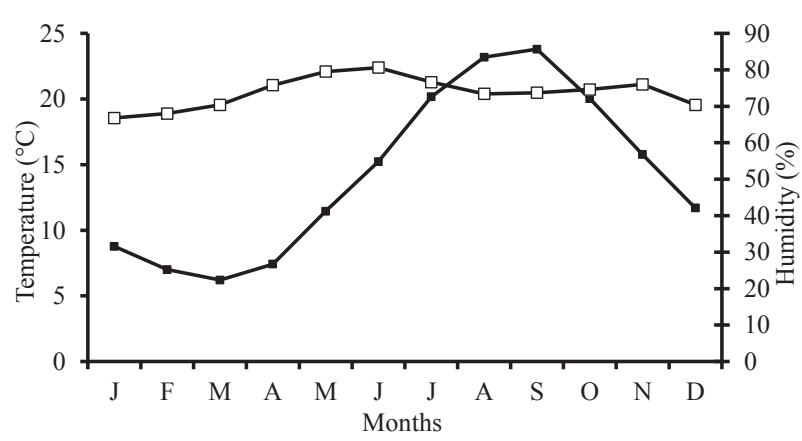

Figure 1. Average monthly temperature $(\boldsymbol{\square})$ and humidity ( $\square$ ) (SMST 2014) 
The animals in each group were grazed between 9:00 and 16:00 $\mathrm{h}$ on pasture during the seasons and were housed as a group for the rest of the day and were fed a total mixed ration, except for winter season. During the winter months animal were fed only a total mixed ration. Total mixed ration was composed of concentrate feed, silage (corn, vetch or grass) and hay (cereal or grass).

Data were subjected to analysis of variance, and calving seasons and milk yield levels were used as main factors, calving age (month) was used as covariant and calving year was used as dummy factor in the model under the GLM model of SPSS. The differences between the means were compared by LSD test and the means were presented as standard error of the mean.

\section{Results and discussion}

Calving season affected the days from calving to first insemination (Table 2). High yielding cows were inseminated $42-d$ later in summer season than those calved in winter season. Similar results were obtained for cows producing moderate milk yield $(\mathrm{P}<0.001)$. There were, however, no effects of calving season on the days from calving to first insemination in low producing cows $(\mathrm{P}>0.05)$.

The increase in milk yield increased the days from calving to the first insemination (Table 2) $(\mathrm{P}<0.001)$. High producing cows $(104.0 \pm 3.4 \mathrm{~d})$ were inseminated 44 days later $(\mathrm{P}<0.001)$ than low producing cows $(59.5 \pm 3.3 \mathrm{~d})$.

Table 1. Classification of the data into calving months and lactation milk yield groups

\begin{tabular}{lccc}
\hline Calving season & Months & $\mathrm{n}$ & Lactation milk yield (kg) \\
\hline Winter & December-February & 380 & $3275.4 \pm 36.2$ \\
\hline Spring & March-May & 319 & $3236.3 \pm 44.0$ \\
\hline Summer & June-August & 287 & $3104.3 \pm 40.2$ \\
\hline Autumn & September-November & 283 & $3135.5 \pm 40.2$ \\
\hline \multicolumn{1}{c}{ Level of milk yield } & Range $(\mathrm{kg})$ & $\mathrm{n}$ & \\
\hline Low & $1522-2478$ & 188 & $2158.5 \pm 18.5$ \\
\hline Average & $2479-3914$ & 893 & $3160.3 \pm 12.3$ \\
\hline High & $3915-7116$ & 188 & $4401.0 \pm 35.6$ \\
\hline
\end{tabular}

Table 2. Days from calving to first insemination in Jersey cows with different milk yields calving in different seasons (days)

\begin{tabular}{lcccc}
\hline \multirow{2}{*}{ Calving season } & \multicolumn{4}{c}{ Level of milk yield } \\
\cline { 2 - 5 } & Low & Moderate & High & Overall \\
\hline Winter & $59.4 \pm 6.0$ & $67.1 \pm 2.6^{\mathrm{b}}$ & $86.0 \pm 5.7^{\mathrm{b}}$ & $70.8 \pm 2.9^{\mathrm{a}}$ \\
\hline Spring & $52.0 \pm 6.6$ & $80.0 \pm 3.0^{\mathrm{a}}$ & $101.8 \pm 5.9^{\mathrm{b}}$ & $77.9 \pm 3.1^{\mathrm{ab}}$ \\
\hline Summer & $64.1 \pm 6.7$ & $79.8 \pm 3.0^{\mathrm{a}}$ & $128.4 \pm 7.4^{\mathrm{a}}$ & $90.8 \pm 3.5^{\mathrm{c}}$ \\
\hline Autumn & $62.4 \pm 6.7$ & $84.4 \pm 3.2^{\mathrm{a}}$ & $99.7 \pm 7.5^{\mathrm{b}}$ & $82.2 \pm 3.5^{\mathrm{bc}}$ \\
\hline Overall & $59.5 \pm 3.3^{\mathrm{A}}$ & $77.8 \pm 1.5^{\mathrm{B}}$ & $104.0 \pm 3.4^{\mathrm{C}}$ & \\
\hline
\end{tabular}

$\mathrm{a}, \mathrm{b}, \mathrm{c}-$ Values in the same column with different letters differ significantly $(\mathrm{P}<0.001)$

A, B, C - Values within row with different letters differ significantly $(\mathrm{P}<0.001)$

Table 3. Days open in Jersey cows with different milk yields calving in different seasons (days)

\begin{tabular}{ccccc}
\hline \multirow{2}{*}{ Calving season } & \multicolumn{4}{c}{ Level of milk yield } \\
\cline { 2 - 5 } & Low & Moderate & High & Overall \\
\hline Winter & $67.5 \pm 7.0$ & $82.5 \pm 3.1^{\mathrm{b}}$ & $116.4 \pm 6.7^{\mathrm{b}}$ & $88.8 \pm 3.4^{\mathrm{c}}$ \\
\hline Spring & $68.8 \pm 7.7$ & $97.3 \pm 3.5^{\mathrm{a}}$ & $132.1 \pm 6.8^{\mathrm{ab}}$ & $99.4 \pm 3.6^{\mathrm{d}}$ \\
\hline Summer & $69.3 \pm 7.9$ & $88.7 \pm 3.5^{\mathrm{ab}}$ & $151.2 \pm 8.7^{\mathrm{a}}$ & $103.1 \pm 4.1 \mathrm{~d}$ \\
\hline Autumn & $70.1 \pm 7.9$ & $93.8 \pm 3.8^{\mathrm{a}}$ & $129.8 \pm 8.8^{\mathrm{ab}}$ & $97.9 \pm 4.1^{\mathrm{cd}}$ \\
\hline Overall & $68.9 \pm 3.9^{\mathrm{A}}$ & $90.6 \pm 1.7^{\mathrm{B}}$ & $132.4 \pm 4.0^{\mathrm{C}}$ & \\
\hline
\end{tabular}

Values in the same column with different letters differ significantly, a, b: $(\mathrm{P}<0.001)$; c, d: $(\mathrm{P}<0.05)$

$A, B, C$ - Values in the same row with different letters differ significantly differ significantly $(\mathrm{P}<0.001)$ 
Days open in high producing cows calved in summer months (151.2 $\pm 8.7 \mathrm{~d})$ were 35 days longer $(\mathrm{P}<0.001)$ than those calved in winter months $(116.4 \pm 6.7$ d). Similar results were observed for cows with moderate milk yield $(\mathrm{P}<0.01)$. However, there were no effects of calving season on the days open in low producing cows $(\mathrm{P}>0.05)$.

Days open increased (Table 3; $\mathrm{P}<0.001$ ) with the increase in milk yield. Days open in high yielding cows $(132.4 \pm 4.0$ d) were 63 days longer $(\mathrm{P}<0.001)$ than those in low yielding cows $(68.9 \pm 3.9 \mathrm{~d})$.

There was no effect of calving season on calving interval. However, calving interval was 18 days longer $(\mathrm{P}<0.05)$ in high producing cows calved in spring (388.1 $\pm 7.7 \mathrm{~d})$ than in those calved in winter months $(367.9 \pm 6.9 \mathrm{~d})$. Calving interval significantly increased $(\mathrm{P}<0.001)$ with the increase in milk yield (Table 4). Calving interval was 26 days longer in high yielding cows $(377.6 \pm 4.5 \mathrm{~d})$ than those in low yielding cows $(351.1 \pm 4.7)$.

Calving season did not affect first service conception in low producing cows (Table 5), but affected in high producing cows $(\mathrm{P}<0.05)$. First service conception rate was $56 \%$ in high yielding Jersey cows calved in summer and $85 \%$ in those calved in autumn.

Services per conception in cows calved in autumn were lower than in cows calved in other seasons (Figure 2; $\mathrm{P}<0.001$ ).

The results of present study showed that the days from calving to first insemination, services per conception, days open and calving interval were affected negatively in high producing cows calved in summer months. This was probably caused by the high temperatures occurred in summer months and/or poor vegetation.

High temperatures during summer months have been reported to decrease the length and intensity of estrus behaviors, increase the length of anoestrus period and increase the silent ovulation rate (Roth et al., 1997; Wolfenson et al., 2000; Rensis et al., 2002).

Consequently, services per conception increase and first service conception rate decrease due to these changes (Ray et al., 1992; Hansen, 1994; Barash et al., 2001; Rensis et al., 2002). In the present study, services per conception were found $27 \%$ higher and first service conception rate $22 \%$ lower in high producing cows calved in summer than

Table 4. Calving interval in Jersey cows in different milk yields calving in different seasons (days)

\begin{tabular}{lcccc}
\hline \multirow{2}{*}{ Calving season } & \multicolumn{4}{c}{ Level of milk yield } \\
\cline { 2 - 5 } & Low & Moderate & High & Overall \\
\hline Winter & $347.0 \pm 9.8$ & $369.1 \pm 3.5^{\mathrm{ab}}$ & $369.7 \pm 6.9^{\mathrm{b}}$ & $362.0 \pm 4.2$ \\
\hline Spring & $352.5 \pm 10.5$ & $361.0 \pm 4.4^{\mathrm{b}}$ & $388.1 \pm 7.7^{\mathrm{a}}$ & $367.2 \pm 4.6$ \\
\hline Summer & $355.4 \pm 8.7$ & $373.2 \pm 3.9^{\mathrm{a}}$ & $382.9 \pm 11.8^{\mathrm{ab}}$ & $370.5 \pm 5.1$ \\
\hline Autumn & $349.6 \pm 8.1$ & $363.6 \pm 3.9^{\mathrm{ab}}$ & $369.6 \pm 8.4^{\mathrm{ab}}$ & $360.9 \pm 4.1$ \\
\hline Overall & $351.1 \pm 4.7^{\mathrm{A}}$ & $366.7 \pm 2.0^{\mathrm{B}}$ & $377.6 \pm 4.5^{\mathrm{C}}$ & \\
\hline
\end{tabular}

a, b - Values in the same column with different letters differ significantly $(\mathrm{P}<0.001)$

$\mathrm{A}, \mathrm{B}, \mathrm{C}$ - Values within row with different letters differ significantly $(\mathrm{P}<0.001)$

Table 5. First service conception rate in Jersey cows with different milk yields calving in different seasons

\begin{tabular}{lcccc}
\hline \multirow{2}{*}{ Calving season } & \multicolumn{4}{c}{ Level of milk yield } \\
\cline { 2 - 5 } & Low & Moderate & High & Overall \\
\hline Winter & 0.63 & 0.72 & $0.78^{\mathrm{ab}}$ & 0.72 \\
\hline Spring & 0.75 & 0.73 & $0.60^{\mathrm{bc}}$ & 0.71 \\
\hline Summer & 0.69 & 0.71 & $0.56^{\mathrm{c}}$ & 0.69 \\
\hline Autumn & 0.82 & 0.89 & $0.85^{\mathrm{a}}$ & 0.87 \\
\hline Overall & 0.72 & 0.76 & 0.70 & 0.74 \\
\hline
\end{tabular}

$\mathrm{a}, \mathrm{b}, \mathrm{c}$ - Values in the same column with different letters differ significantly $(\mathrm{P}<0.05)$ 
those calved in winter months. On the other hand, the longer days from calving to first insemination in cows calved in summer months might be caused by the changes in concentrations of reproductive hormones due to higher temperatures (Jonsson et al., 1997; Roth et al., 1997; Wolfenson et al., 2000) or the degenerations in uterus endometrium morphology and functions (Sahaham-Albalancy et al., 1996a,b). Furthermore, antagonistic effects among the reproductive hormones might have affected these traits (Hansen et al., 2001). While some researchers reported that higher temperatures decreased the progesterone concentration, interferon tau (IFN- $\tau$ ) production and the segregations of cytokines (Wise et al., 1988; Wolfenson et al., 1988), the others reported that higher temperatures increased the amount of $\mathrm{PGF}_{2 \alpha}$ secreted from endometrium (Rocha et al., 1998; Wolfenson et al., 2000). In this case, lower plasma progesterone concentrations cause abnormal follicle development and decrease the quality of oocytes during the pre-mating period. The decreases in interferon tau (IFN- $\tau$ ) production and in the amount of cytokine secretion inhibit the maternal recognition of pregnancy. The increases in the amounts of $\mathrm{PGF}_{2 \alpha}$ cause early embryonic losses. Consequently, first service conception rate might be decreased and service per conception might be increased due to the higher temperatures. However, during the evaluation data, we had no chance to veterinary and biochemistry check-up of dairy cows.

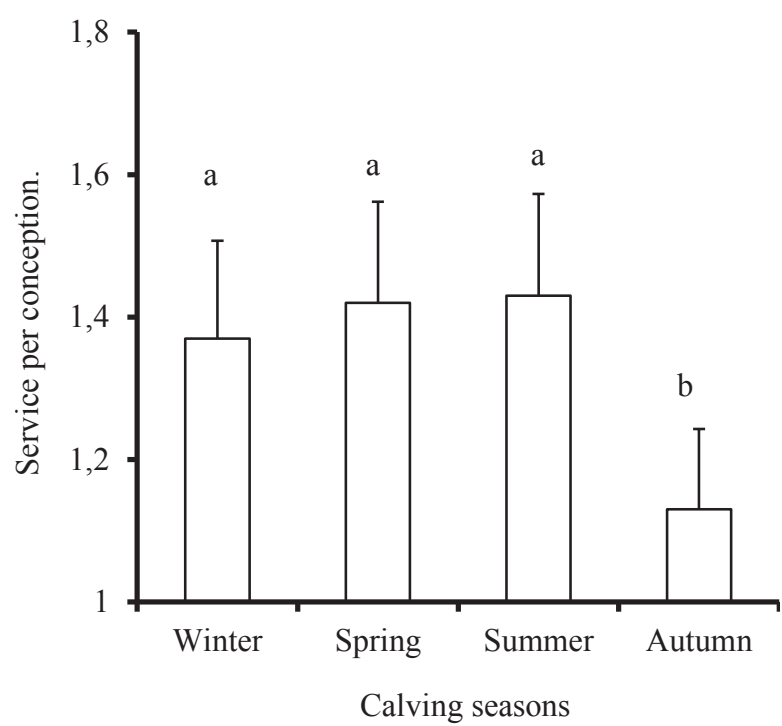

Figure 2. Services per conception in Jersey cows calved in different seasons
They had been already lived. In the present study, the higher first service conception rate obtained in cows calved in autumn confirmed the view that the cows calved in summer are more negatively affected by higher temperatures. The higher first service conception rate in cows calved in autumn might be due to the fact that these cows were inseminated in winter. Conversely, lower first service conception rates in cows calved in summer might be explained by the fact that these cows were inseminated in autumn and also autumn fertility was negatively affected by the delayed negative effect of heat stress occurred in summer months (Roth et al., 1997; Wolfenson et al., 2000).

Nutrition is one of the most important factors affecting the reproductive performance. In lactating cows, short-term deficient or excess nutrition in terms of protein and/or energy in early lactation have negative effects on post-partum ovarian activity, pregnancy and fertility, especially in high producing cows (Butler, 2000). Protein content of diet has significant effects on reproductive performance. Businga et al. (1996) and Butler (2000) showed that the proteins with higher ruminal degradability affected the reproductive performance negatively by decreasing blood plasma progesterone concentrations or by increasing blood urea and ammonia concentrations. Excess protein consumption is common in high producing cows due to the high metabolic demand. Consequently, plasma progesterone is degraded rapidly or urea and ammonia concentrations increase due to the lack of suitable protein and fermentable energy in rumen or the uterine environment $\mathrm{pH}$ might be changed. Lower plasma progesterone levels or higher nitrogen concentration levels were found highly related to decreases in fertility in cows (Butler, 1998). On the other hand, metabolizable energy and crude protein contents of pastured vegetation decrease in summer season and consequently, the intakes of nutrients and their digestibility will be limited. Thus, insemination of cows in summer months, during which range plants mature, might have increased service per conception and days open and might have decreased pregnancy rate due to the inadequate protein and/or energy intake. Also, the precursor content of vitamins in forages might be quite poor in summer. Conversely, days from calving to first estrus, fertilization, embryo quality and development might be affected nega- 
tively due to the higher ammonia or urea $\mathrm{N}$ accumulation in rumen or progesterone and $\mathrm{PGF}_{2 \alpha}$ synthesis caused by unsaturated fatty acid contents (Gath et al., 1999). So, abnormal follicules might be developed, oocyte quality might be decreased and early embryonic losses might be occurred when insemination in these cows coincide with this period. As in present study, days from calving to first insemination increases, the first service conception rate decreases or services per conception increases. However, the fatty acid contents of winter rations (grass or corn silage) used in present study might have been different from those of spring and summer rations. Corn silage might have increased $\mathrm{PGF}_{2 \alpha}$ synthesis due to its high linoleic acid content and so might have decreased the days from calving to the first insemination by stimulating follicular development in cows calved in winter. Furthermore, the first months of pregnancy in these cows coincide with pasture season. So, fresh pasture hays might have maintained the pregnancy by stimulating the progesterone synthesis due to their higher linoleic acid contents since it is the precursor of steroid hormones.

The present longer days from calving to the first insemination in high producing cows compared to those in low producing cows supports the findings of Faust et al. (1988), Horrison et al. (1990), Jordan and Fourdraine (1993) and Nebel and McGilliard (1993). These researchers reported that the days from calving to the first insemination increased with the increase in milk yield. Nutrient requirements of cows increase with the increase in milk yield and cows might enter a state of negative energy balance after calving. As the negative energy balance affects days from calving to the first ovulation, the days from calving to the first insemination and so days open negatively and consequently, calving interval increases (Tesfa et al., 1999; Butler, 2000). Similarly, in the current study, days from calving to the first insemination was found higher in high producing cows compared to low producing cows. This might be attributed to their low body condition score during early lactation. Because it was determined that the days from calving to the first estrus is longer and services per conception are higher (Tesfa et al., 1999).

As the days from calving to the first insemination affects the days open and calving interval directly, a change in the days from calving to the first insemination might increase or decrease the days open and calving interval. This relationship is also valid so that the increase or decrease in first service conception rate can lead to increase or decrease in service per conception and also can increase or decrease the days open and calving interval. Consequently, it can be said that the factors affecting the days from calving to the first insemination and first service conception rate can also affect the days open, service per conception and calving interval.

In conclusion, the days from calving to the first insemination increased, first service conception rate decreased, services per conception increased and consequently days open and calving interval increased in high producing cows calved in spring and summer, suggesting that breeding and calving season may need to be pre-programmed in high yielding herds to eliminate the adverse effects of summer season on reproductive performance of dairy cows. In addition to this, a good feeding management will enhance ideal body condition score and uterus health to get a sustainable profit in dairy farm.

\section{Utjecaj sezone teljenja na reproduktivne karakteristike Jersey krava}

\section{Sažetak}

Tijekom 16 godina s jedne državne farme prikupljeni su podaci o mliječnosti 462 Jersey mliječne krave koji su sadržavali 1269 zaključenih laktacija. Također, prikupljeni su podaci o reproduktivnim karakteristikama krava. Prosječne vrijednosti laktacijske proizvodnje mlijeka, intervala teljenja, servis perioda, intervala od teljenja do prvog osjemenjivanja, duljine laktacije, duljine graviditeta i duljine suhostaja iznosili su: $3195,7 \pm 20,2 \mathrm{~kg}$, $366,6 \pm 1,7$ dana, 92,9 $\pm 1,6$ dana, 78,0 $\pm 1,3$ dana, $301,7 \pm 1,1$ dana, $275,2 \pm 0,2$ dana i 69,3 $\pm 0,8$ dana. Utvrđen je utjecaj sezone teljenja (zima, proljeće, ljeto i jesen) na reproduktivne karakteristike visoko, nisko i umjereno proizvodnih mliječnih krava. Sezona teljenja utječe na dane od teljenja do prvog osjemenjivanja kod visoko i umjereno mliječnih krava $(\mathrm{P}<0,001)$, dok nije utjecala na nisko mliječne krave. Ljeti je servis period krava s visokim proizvodnjom bio 35 dana dulji $u$ odnosu na zimsku sezonu 
$(\mathrm{P}<0,001)$, jednako kao i kod umjereno mliječnih krava $(\mathrm{P}<0,01)$. Kod visokomliječnih krava, interval teljenja bio je 18 dana dulji tijekom proljeća u odnosu na zimsku sezonu teljenja. Sezona teljenja također je utjecala na stopu prvog uspješnog osjemenjivanja kod visokomliječnih krava $(\mathrm{P}<0,05)$. Indeks osjemenjivanja $\mathrm{u}$ jesen bio je manji nego tijekom ostalih sezona $(\mathrm{P}<0,001)$. Zaključno, visokomliječne krave trebaju više pažnje u ljetnoj sezoni kada je riječ o stanju kondicije, omjeru energije i proteina u obroku, zdravlju maternice i eliminacije toplinskog stresa, kako bi se ostvario veći profit na mliječnoj farmi.

\section{Ključne riječi: Jersey krava, reproduktivne karakteristike, sezona teljenja}

\section{References}

1. Barash, H., Silanikove, N., Shamay, A., Ezrat, E. (2001): Interrelationships among ambient temperature, day lenght, and milk yield in dairy cows under a Mediterranean climate. Journal of Dairy Science 84, 2314-2320. https://doi.org/10.3168/jds.S0022-0302(01)74679-6

2. Boichard, D., Barbat, A., Briend, M. (1998): Evaluation genetique des caracteres de fertilite femelle chez les bovines laitiers. Recontres Recherche Ruminants 5, 103106.

3. Butler, W.R., Smith, R.D. (1989): Interrelationships between energy balance and postpartum reproductive function in dairy cattle. Journal of Dairy Science 72, 767-783. https://doi.org/10.3168/jds.S0022-0302(89)79169-4

4. Butler, W.R. (2000): Nutritional interactions with reproductive performance in dairy cattle. Animal Reproduction Science 60-61, 449-457. https://doi.org/10.1016/S0378-4320(00)00076-2

5. Calus M.P., Windig, J.J., Veerkamp, R.F. (2005): Associations among descriptors of herd management and phenotypic and genetic levels of health and fertility. Journal of Dairy Science 88, 2178-89. https://doi.org/10.3168/jds.S0022-0302(05)72893-9

6. Chevallier, A., Humblot, P. (1998): Evolution des taux de non retour apres insemination artificielle: effet du controle du delai de mise a la reproduction sur les resultats de fertilite. Rencontres Recherche Ruminants 5, 75-77.

7. Coffey, M.P., Simm, G., Oldham, J.D., Hill, W.G. Brotherstone, S. (2004): Genotype and diet effects on energy balance in the first three lactations of dairy cows. Journal of Dairy Science 87, 4318-4326. https://doi.org/10.3168/jds.S0022-0302(04)73577-8

8. De Rensis, F., Scaramuzzi, R.J. (2003): Heat stress and seasonal effects on reproduction in the dairy cow- a review. Theriogenology 60, 1139-1151. https://doi.org/10.1016/S0093-691X(03)00126-2
9. Doepel, L., Lapierre, H., Kennelly, J.J. (2002): Peripartum performance and metabolism of dairy cows in response to prepartum energy and protein intake. Journal of Dairy Science 85, 2315-2334. https://doi.org/10.3168/jds.S0022-0302(02)74312-9

10. Fahey, J., O'Sullivan, K., Crilly, J., Mee, J.F. (2002): The effect of feeding and management practices on calving rate in dairy herds. Animal Reproduction Science 4, 133-50. https://doi.org/10.1016/S0378-4320(02)00192-6

11. Freret, S., Chevallier, A. (2002): Fecondite des vaches laitieres: point de vue dune cooperative dinsemination artificielle. Evolution depuis 1987 sur la zone URCO. AERA, Reproduction Genetique et Performances, Paris, 6 Decembre 2002, AERA Ed, Lyon, pp. 11-16.

12. Garcia-Peniche, T.B. (2004): Comparisons of Holstein, Brown Swiss, and Jersey cows for age at first calving, first calving interval, and true herd-life up to five years of age in seven regions of the United States. PhD Thesis, Blacksburg.

13. Garcia-Ispierto, I., Lopez-Gatius, F., Bech-Sabat, G., Santolaria, P., Yaniz, J.L., Nogareda, C., De Rensis, F., Lopez-Bejar, M. (2007): Climate factors affecting conception rate of high producing dairy cows in northeastern Spain. Theriogenology 67, 1379-1385. https://doi.org/10.1016/j.theriogenology.2007.02.009

14. Grimard, B., Freret, S., Chevallier, A., Pinto, A., Ponsart, C., Humblot, P. (2006): Genetic and environmental factors influencing first service conception rate and late embryonic/foetal mortality in low fertility dairy herds. Animal Reproduction Science 91, 31-44. https://doi.org/10.1016/j.anireprosci.2005.03.003

15. Hansen, P.J., Arechiga, C.F. (1999): Strategies for managing reproduction in the heat-stressed dairy cows. Journal of Dairy Science 82 (Suppl. 2): 36-50.

16. Jordan, E.R. (2003): Effects of heat stress on reproduction. Journal of Dairy Science 86 (E. Supplement): E104-E114. https://doi.org/10.3168/jds.S0022-0302(03)74043-0

17. Kadzere, C.T., Murphy, M.R., Silanikove, N., Maltz, E. (2002): Heat stress in lactating dairy cows: a review. Livestock Production Science 77, 59-91. https://doi.org/10.1016/S0301-6226(01)00330-X

18. Lopez-Gatius, F. (2003): Is fertility declining in dairy cattle? A retrospective study in northeastern Spain. Theriogenology 60, 89-99. https://doi.org/10.1016/S0093-691X(02)01359-6

19. Lopez-Gatius, F., Santolaria, P., Mundet, I., Yaniz, J.L. (2005): Walking activity at estrus and subsequent fertility in dairy cows. Theriogenology 63, 1419-29. https://doi.org/10.1016/j.theriogenology.2004.07.007

20. Lucy, M.C., (2001): Reproductive loss in highproducing dairy cattle: where it will end? Journal of Dairy Science 84, 1277-1293. https://doi.org/10.3168/jds.S0022-0302(01)70158-0

21. Macmillan, K.L., Lean, I.J., Westwood, C.T., (1996). The effects of lactation on the fertility of dairy cows. Australian Veterinary Journal 73, 141-147. https://doi.org/10.1111/j.1751-0813.1996.tb10007.x 
22. Muller, C.J.C., du Toit, F.J., Singhapol, C., Botha, J.A. (2000): The effect of milk yield on some reproductive parameters of the Elsenburg Holstein and Jersey herds. South African Journal of Animal Science 30 (1), 34-35. https://doi.org/10.4314/sajas.v30i4.3898

23. Němečková, D., Stádník, L., Čítek, J. (2015): Associations between milk production level, calving interval length, lactation curve parameters and economic results in Holstein cows. Mljekarstvo 65 (4), 243-250. https://doi.org/10.15567/mljekarstvo.2015.0404

24. O'Callaghan, D., Boland, M.P. (1999): Nutritional effects on ovulation, embryo development and the establishment of pregnancy in ruminants. Animal Science 6, 299-314. https://doi.org/10.1017/S1357729800050311

25. Pryce, J.E., Royal, M.D., Garnsworthy, P.C., Mao, I.L. (2004): Fertility in the high yielding dairy cow. Livestock Production Science 86, 125-135. https://doi.org/10.1016/S0301-6226(03)00145-3

26. Pryce, J.E., Veerkamp, R.F. (2001): The incorporation of fertility indices in genetic improvement programmes. BSAS Occasional Publication 26, 237-250.
27. Roche, J.F, Mackey, D., Diskin, M.D. (2000): Reproductive management of postpartum cows. Animal Reproduction Science 60/61, 703-712. https://doi.org/10.1016/S0378-4320(00)00107-X

28. Roth, Z., Meidan, R., Shaham-Albalancy, A., Wolfenson, D. (1997): Immediate and delayed effects of heat stress on follicular development and function in lactating cows. Ann. Meeting, Am. Soc. Anim. Sci., Nashville, Abstract 367.

29. Royal, M.D., Darwash, A.O., Flint, A.P.F., Webb, R., Woolliams, J.A., Lamming, G.E. (2000): Declining fertility in dairy cattle: changes in traditional and endocrine parameters of fertility. Animal Science 70: 478-501. https://doi.org/10.1017/S1357729800051845

30. Sattar, A., Mirza, R.H., Ahmad, I. (2004): Reproductive efficiency of Jersey cows under subtropical Conditions of the Punjab. Pakistan Veterinary Journal 24(3), 129133.

31. Wolfenson, D., Roth, Z., Meidan, R. (2000): Impaired reproduction in heat-stressed cattle: basic and applied aspects. Animal Reproduction Science 60-61, 535-547. https://doi.org/10.1016/S0378-4320(00)00102-0 